\title{
The student voice in using eportfolios to address professional standards in a teacher education programme
}

\author{
Lyn Lewis ${ }^{1}$ and Philippa Gerbic ${ }^{1}$ \\ lylewis@aut.ac.nz; pgerbic@aut.ac.nz \\ ${ }^{1}$ School of Education, Auckland University of Technology, New Zealand
}

\begin{abstract}
Electronic portfolios (eportfolios) are presented in the literature as a technological tool with significant potential for professional application. In New Zealand the introduction of eportfolios is a recent innovation, and not much is known about the ways in which learners view this technology or the ways in which it might support their learning and development, particularly against professional standards. This paper reports on findings from a research project conducted in $\mathbf{2 0 1 0}$ with a group of Bachelor of Education (Primary) students at a New Zealand university. The research project sought student perspectives of their learning through eportfolios and around Graduating Standards. Three main findings are discussed: firstly authentic assessment related to Graduating Standards provides reassuring evidence to pre-service student teachers of their growth and development towards beginning teacher status. Secondly, eportfolio activities can support a range of thinking skills linked to standards-achievement. Thirdly, eportfolios and Graduating Standards are perceived by preservice students to have value for employability. The argument is made that deep learning through standards-based assessment is possible when eportfolios are conceptualized as both product and process. We make recommendations regarding eportfolio use for standards-based assessment which include developing authentic learning activities; supporting student-centred eportfolio pedagogy; and the articulation of deep learning outcomes.
\end{abstract}

Keywords: Mahara, eportfolios, graduating standards, qualitative research, student voice.

\section{Introduction}

Electronic portfolios (eportfolios) are being described in glowing terms: "the next great innovation in education" (Gathercole, Crowe, Karayan, McCambridge, Maliski, Love \& McKean, 2007, p. 641) and the "potential to be transformational for colleges and universities" (Stefani, Mason \& Pegler, 2007, p. 2). The eportfolio is being evaluated in an increasing number of institutions as a tool for both formative developmental learning and for summative assessment and accreditation purposes. While a process/product tension was identified in eportfolios a decade ago (Darling, 2001) there is now a wider view which recognises co-existence of, rather than tension between, product and process (JISC, 2008).

Eportfolios can be used for evidencing the achievement of standards, whether these are internal assessment criteria, graduate attributes or an external set of Graduating or Registration Standards. With a summative focus on presenting evidence of achievement, the assessment or presentation portfolio is commonly identified with standards-based processes. However, embedded within such achievement, processes more closely associated with a learning or developmental portfolio may be present. While acknowledging that the presentation of artefact evidence and self-appraisal against standards may be demonstrated through eportfolios, we argue that a challenge exists for students to articulate their learning

Lewis, L., \& Gerbic, P. (2012). The student voice in using eportfolios to address professional standards in a teacher education programme. Journal of Teaching and Learning for Graduate Employability, 3(1), 17 - 25. 
through this process. The purpose of this paper is to report on a research project which explored student perspectives of their summative (product) and formative (process) learning through using eportfolio for assessment of the Graduating Teacher Standards (GTS).

\section{Literature Review}

GTS were introduced to New Zealand pre-service tertiary education programmes in 2007 by the New Zealand Teachers Council. Programmes leading to teacher registration are required to show evidence of accommodating these standards. The US model differs in that it requires students themselves to demonstrate, via a portfolio to assessors, that they meet standards before gaining a teaching license (Strudler \& Wetzel, 2005; Milman, 2005). Gathercole et al., (2007) argue that meeting standards through eportfolio use should be considered both a challenge and an opportunity. A challenge exists for lecturers to work with standards-based teaching which is engaging and meaningful for students. An opportunity exists in that portfolios, while having a summative appraisal purpose, can also be formative and focus on holistic professional learning. The authors contend that rather than being constraining "standards-based instruction can and should be a rich, integrated, informative and engaging process" (p. 644).

Electronic portfolios are an ideal vehicle for evidencing achievement of such standards through their potential to support the synthesis of theory and practice (Strudler \& Wetzel, 2005), demonstrate professional growth and development over time (Barrett, 2005) and facilitate reflective practice (Stefani \& Mason, 2007; Lin, 2008). JISC's definition of eportfolios (2008) integrates the development (process) and assessment (product) aspects of portfolios:

"an eportfolio is the product, created by the learner, a collection of digital artefacts articulating experiences, achievements and learning. Behind any product or presentation, lie rich and complex processes of planning, synthesising, sharing, discussing, reflecting, giving, receiving and responding to feedback. These processes referred to here as 'eportfolio-based learning' - are the focus of increasing attention, since the process of learning can be as important as the end product" (p.6).

So, rather than a tick-box approach to achievement, an eportfolio pedagogy which emphasises the kinds of deep learning activities highlighted above can be valuable in standards settings.

\section{Deep learning through use of an eportfolio associated with standards}

The pedagogy associated with a standards-based eportfolio is based on a constructivist approach to learning which involves meaning-making as a cognitive strategy. Students selfappraise, reflect and evaluate upon their experiences and learning (Gathercole et al, 2007). Pelliccione and Dixon (2008) found that the level of students' analytical skills deepened over time and their ability to articulate their transfer of learning to professional practice showed a more meaningful understanding of their holistic self.

While reflection is strongly linked with personal and professional development processes over time, it is also a significant aspect of self-appraisal against standards. Much of the literature reports on the eportfolio as a tool for promoting reflective thinking and reflective practice, consciously drawing on student's values and beliefs as they consider their personal and professional strengths and weaknesses (Lyons, 1998; Hallam \& Creagh, 2010). Wetzel and Strudler's research (2006) reported that reflection was a major benefit of eportfolio use. Ring and Foti (2006) talk of the personal authentication of practice through reflection. Such an autonomous professional expression represents authentic transitioning between status as student and that of professional. 
Additional factors related to deep learning opportunities have been identified such as Ring and Foti's (2006) finding that students directly involved in working with standards reported a deeper understanding of the expectations and standards of their profession. Independent learning, greater student engagement and more active learning are associated in the literature with effective learning activities using standards (Wetzel \& Strudler, 2006). Joyes, Grey and Hartnell-Young (2010) identify maximized learning opportunities through the matching of design and support to the purpose and context. Students also become more aware of their marketability and improved chances of employment (Milman, 2005).

While there is an increasing international research base on student responses to the introduction of eportfolios for standards-based assessment (Milman, 2005; Willis, Gravestock \& Jenkins, 2006), only a few studies have focused on student perceptions of their learning during this period. Studies by Ring and Foti (2006), Pelliccione and Dixon (2008) and Wetzel and Strudler (2006) were able to identify learning such as linking theory to practice, critical thinking, reflective thinking skills and analytical skill advancement. However, Lopez-Fernandez and Rodriguez-Illera (2009) in their study of eportfolio use to support learning and assessment found that the expected impact on learning was not as significant as anticipated.

Studies conducted in the Australia/New Zealand region have focused on the introduction of eportfolios which include the student experience (Hallam \& Creagh, 2010; Gerbic, Lewis \& Northover, 2009; Kardos, Cook, Butson \& Kardos, 2009) but do not focus specifically on student perceptions of learning. A gap exists in the literature in New Zealand, around the study of student perspectives of learning through eportfolio use and around graduating standards. This research project is an attempt to start a discussion on meeting both the challenge and opportunity presented by such standards through eportfolio.

\section{The Study}

The study was conducted in the Bachelor of Education (Primary) in a New Zealand university during 2010. Eportfolios and the GTS were introduced together into this programme in 2009 to support students' achievement of the professional standards which were embedded through a redesign of curriculum rather than an 'add-on' to the existing course. The three Practicum papers and the Teaching Technology paper were selected because they have a focus on theory into practice and include an incremental formative focus to the growth and development of students as professionals. Learning activities included goal setting and weekly reflections during practicum periods, as well as assessment pieces directly linked to self-appraisal against specific GTS. Students were required to upload into their eportfolio a detailed reflection in which they appraised their achievement of a GTS. For each Standard, a variety of artefacts relating to professional knowledge, practice or relationships were provided and referenced as evidence of such achievement. In the case of the Technology assessment, students created an eposter of a 'design, make and appraise' project which evidenced, through uploaded files, their learning at the different levels of the project: personal, professional, theory-based and research-informed. The eposter contained a variety of media elements such as images, video and audio which expressed the experience.

Questions relating to eportfolio use for GTS were not asked directly but were embedded in two research questions:

1. How does an eportfolio help students to learn?

2. How does the eportfolio contribute to growth and development of students as emergent professionals? 


\section{Theoretical Framework and Methodology}

A qualitative approach was used which drew on conceptions of naturalistic inquiry (Lincoln \& Guba, 1985) and situated activity (Denzin and Lincoln, 2000). The approach adopted was constructivist, where reality is not a single external truth but a complex, multi-faceted world where each person shapes their own understanding, both individually and within a broader social learning context. This was also insider research. An interpretive methodology provided an approach that was highly suited to presenting the student voice.

Fifty six students across two cohorts were invited to participate in the research study. Data was collected from 14 participants over two semesters, 6 participants in the first semester and 8 in the second semester. Two focus groups each with 3 members was held for each cohort and two participants in each group elected to be individually interviewed. Discussions with the students centred around the value of eportfolios for their professional preparation, learning and employability. The challenges of working with an eportfolio, including issues such as the technology, assessment and time management, were also discussed.

After data collection an inductive approach was taken to analysis. Using NVivo, data was coded and categorized and initial nodes created. These were then refined into the broader themes of technology challenges; weekly practicum reflections; theory into practice; and professional growth and development over time

\section{Results}

Three main findings emerged from the data:

\section{Authentic assessment related to Graduating Standards provides reassuring evidence for pre-service student teachers of their growth and development towards beginning teacher status}

Learning activities associated with the GTS assignment received positive support and were valued by the participants as authentic links with professional practice and the broader programme aims. They appreciated the focus brought by the GTS and saw the standards as verifying their practice and giving them a deeper connection with their aspirant profession as a result. They referred to their eportfolios as reflecting who they were as teachers and appreciated the confidence and reassurance this provided them.

Being able to... see the level of reflection that I started with and what depth I get now, then you can just ... see development throughout my time at Uni and being able to look back reinforces the idea that you have improved and you can see it and that makes you more... ... Yeah, you've come from all the way over there. (Student)

The shift towards becoming an autonomous professional was raised in both groups. This was particularly well articulated by another student who talked of taking control of her eportfolio:

I think it allows you to give more of yourself professionally. For example we've just done a technology e-poster assignment....there's a lot of me in there... I wanted to talk about what working with that school meant to me... that gives me an avenue; whether it's useful to the lecturer, it was useful to me because it allowed me to explore some of those thoughts that I had about the assignment.

Lewis, L., \& Gerbic, P. (2012). The student voice in using eportfolios to address professional standards in a teacher education programme. Journal of Teaching and Learning for Graduate Employability, 3(1), 17 - 25. 


\section{Eportfolio activities can support a range of thinking skills linked to achievement of standards}

A range of thinking skills were identified associated with eportfolio use. Purposeful goalfocussed thinking was expressed by several participants who were able to make links between the GTS, their goals and the teaching context. Such thinking has brought into focus for the participants the reality of their professional development.

It's not just a goal or it's not just something they've told you that you have to achieve. It's, well, I can see how you use that in the classroom and where it fits in the classroom (Student).

The new skills of evidencing and relating shifted the focus from a previous practice of seeking theory as supporting evidence, to looking now to include personal practice artefacts. This thinking reinforced the experience and link of student teaching with the programme's developmental path towards a beginning teacher status. The following conversation recorded in a focus group shows the type of thinking in evidencing and relating:

Student: That assignment makes you reflect on yourself a lot more.... being critical and...cause when you're relating it to theory and research, you're comparing what you're doing and experiencing to research and your reading.

Student: Yeah, because ... in our assignments, our evidence would be theory, the references to back-up what we said. But in this case here, we're using our own work that we've produced, as our evidence.

Student: Your reflections would tie in with your goals and so you're getting feedback towards your goals and that's helping you with your assignment.

Student: And you have your artefacts to show that this is what you've achieved.

Student: Even your feedback could be an artefact.

The most easily identified thinking skill for participants was that of reflecting and appraising. The introduction of a new reflective model on practicum which included student accountability and immediate lecturer professional feedback explains the unanimous approval for what was perceived to be a very supportive, affirming and relational process.

the lecturer posed questions and expanded my thinking instead of just leaving it there .... say you did your first week reflection and your lecturer was like 'you're not going deep enough with this' or 'you've missed this point of view', then for your next week, you could improve and sort of become more reflective .. it taught me to go and discuss with my Associate Teacher and other teachers in the community about things I was wondering about... instead of just writing it and thinking 'oh yeah, well that's that reflection done, on to the next (Student).

Participants were able to articulate their learning through the reflective task while on teaching practice. However, they were not aware of embedded reflections in both the GTS and Technology assignments which clearly required students to self-appraise while linking theory to practice. While this was demonstrated in submitted work, all but one participant dismissed the eportfolio as a valuable vehicle for the synthesis of theory and practice.

Lewis, L., \& Gerbic, P. (2012). The student voice in using eportfolios to address professional standards in a teacher education programme. Journal of Teaching and Learning for Graduate Employability, 3(1), 17 - 25. 


\section{Eportfolios and Standards are perceived by pre-service students to have value for employability and in supporting their transition to the workplace}

Not only were participants aware of their increasing IT skills, but the transfer of eportfolio skills to the classroom was perceived not as a possibility, but as an intended practice. Participants were aware of the employment possibilities eportfolios presented and several were planning to give a view to prospective employers:

When you're in an interview and they go 'so how can you give us proof that you have met the standard' you have an artefact that you link and you can pull it up straight on e-portfolio and you can say 'here is proof' (Student).

Overall the participants were able to articulate how the standards-based assessment task extended them in terms of their ownership of professional knowledge and skills and even of knowing themselves as teacher. However, they perceived the role of eportfolio in this learning to be only at the superficial level of storage, rather than recognising its ability to enhance this learning and professional development.

\section{Discussion}

The findings of this study illustrate that eportfolios can operate as both a product and process in a standards setting. The study supports the argument advanced by Barrett and Wilkerson (2004) that congruence between a constructivist learning philosophy and an alignment with national standards is possible. Participants however, separated out the summative elements of the GTS and Technology assignments from the formative learning which they related to reflections during student practicum. Despite probing by the researcher during the focus group discussion, the participants were resistant to acknowledge the GTS and associated eportfolio as a medium for demonstrating process learning.

Discussions with participants about their learning through the eportfolio and the GTS experience revealed a disconnect between their ability to make explicit their thinking about learning and the embedded evidence of such learning within participant responses. The achievement of learning associated with the GTS was made explicit at the product or summative level, but participants had difficulty in identifying or articulating their learning at the process or formative level. It would seem that such deep learning remains hidden for most participants.

Our findings provide an Australasian description of the ways students learn through standards-based eportfolio activities. We endorse Blackburn and Hakel's (2006) findings that goal-focussed thinking sets students up for success. In addition, our participants identified authentic links between the goals and professional classroom practice. The use of eportfolio for evidencing achievement through artefacts is readily accepted by New Zealand students, as was the case in Mason, Pegler and Weller's (2004) study. While learning through reflective activities has been identified in other studies (Wetzel \& Strudler, 2006), our participants noted that it was the timely professional feedback provided by lecturers which provoked them to deeper learning. The use of graduating standards through eportfolio made visible the professional growth of participants over time and thus reinforced their development as autonomous professionals, confident to claim their professional status. Increasingly, the participants are valuing the evidence the GTS provide in their eportfolios as a support when seeking employment.

This study indicates emergent evidence of some participants beginning to take control of their eportfolios and justifying personal learning reasons for doing so. This highlights the importance of developing autonomy and ownership of the eportfolio process, particularly in more mature eportfolio users (Strudler \& Wetzel, 2005). These participants had been well grounded, prepared and supported through the GTS assessment and reflective activities by

Lewis, L., \& Gerbic, P. (2012). The student voice in using eportfolios to address professional standards in a teacher education programme. Journal of Teaching and Learning for Graduate Employability, 3(1), 17 - 25. 
committed lecturers. The challenge is to encourage these users to become student-centred, self-regulated 'owners' of their eportfolios; users who recognise the value of the eportfolio as a developmental tool for deep learning.

The discussion and recommendations which follow need to be read in the light of the limitations of this research study. Bearing in mind the theoretical perspectives of interpretivism and constructivism, and that each individual's contribution to the research is valid and meaningful as an expression of their experience, it must be acknowledged that the sample size was small. However, it did draw from two different cohorts of students. Furthermore the positive findings around learning through reflection should be tempered by the fact that teacher education has a culture of reflection and students find it relatively easy to write in-depth about their professional practice. Eportfolio reflections introduced in other disciplines are reported to meet strong student resistance (Kardos, Cook, Butson \& Kardos, 2009).

\section{Recommendations}

Based on this research we offer the following recommendations:

- Standards-based assessment may stimulate deep learning and trigger professional growth, however, the focus should be on developing authentic learning activities where standards are embedded in curriculum and students are guided towards deeper learning, rather than viewing the standards as a tick-box goal. In the same way, the eportfolio itself needs to be viewed and used as pedagogy and process rather than product (JISC, 2008).

- The role of the lecturer in the initial stages of implementation of eportfolio and standards is important. However, shifting locus of control from the lecturer to the student needs to happen once competency levels have been achieved. A shift towards a more student-centred, self-regulated and highly individual response is an important development of eportfolio pedagogy.

- Students need to be encouraged to think about and articulate the process or developmental learning that lies hidden beneath the more easily accessible explicit learning outcomes related to the product aspect of standards-based assessment. The reflective capacity of the eportfolio makes it an ideal vehicle for such metacognition.

\section{Conclusion}

This report has focussed on student perceptions of their learning and professional development through eportfolios, linked to Graduating Standards. Analysis of the data has revealed three findings. Firstly, students find reassurance in the achievement of authentic assessments related to Graduating Standards which validate their emerging professional status. Secondly, using eportfolios for standards-based assessments involve new thinking skills which are not always easily articulated by users and thirdly, eportfolios and Standards are perceived by pre-service students to have value for employability through their evidential nature.

It is important to recognise that it is not the eportfolio technology that has achieved this but the learning design which wraps around it as "it is the pedagogy, not the tool that comes first" (JISC, 2008, p. 17). This approach creates curriculum renewal and opportunities for transformation. Deep learning related to achievement of professional standards can be supported by eportfolios particularly if the assessment and developmental aspects of eportfolios can be synchronized. In this way, eportfolios might enact their transformative potential.

A version of this paper was presented at the ePortfolios Australia Conference 2011, Perth, Western Australia, 17 - 18 October, 2011.

Lewis, L., \& Gerbic, P. (2012). The student voice in using eportfolios to address professional standards in a teacher education programme. Journal of Teaching and Learning for Graduate Employability, 3(1), 17 - 25. 


\section{References}

Barrett, H. (2005). The REFLECT Initiative: White Paper. Researching electronic portfolios and learner engagement. Retrieved from http://electronicportfolios.com/portfolios.html

Barrett, H. \& Wilkerson, J. (2004). Conflicting paradigms in electronic portfolio approaches. Retrieved from http://electronicportfolios.com/systems/paradigms.html

Blackburn, J. \& Hakel, M. (2006). Enhancing self-regulation and goal orientation with eportfolios. In A. Jafari \& C. Kaufman (Eds.), Handbook of research on eportfolios, (pp. 83-89). Hershey, PA: Idea Group Reference.

Darling, L. (2001). Portfolio as practice: The narratives of emerging teachers. Teacher and Teacher Education, 17(1), 107-121.

Denzin, N., \& Lincoln, Y. (2000). The discipline and practice of qualitative research. In N. Denzin \& Y. Lincoln (Eds.), Handbook of Qualitative Research (2nd ed.). Thousand Oaks, CA: Sage Publications.

Gathercoal, P., Crowe, J., Karayan, S., McCambridge, T., Maliksi, S., Love, D., \& McKean, G. (2007). Webfolios: Authentic of state and accreditation standards. In T. Townsend \& R. Bate (Eds.), Handbook of Teacher Education, (pp. 641-656). Netherlands: Springer.

Gerbic, P., Lewis, L., \& Northover, M. (2009). Student perspectives of eportfolios: A longitudinal study of growth and development. In R. Atkinson \& C. McBeath (Eds.), Same Places, Different Spaces, Proceedings of the $26^{\text {th }}$ Annual Ascilite Conference, 2009. Auckland, New Zealand. Retrieved from: http://www.ascilite.org.au/conferences/auckland09/procs/gerbic.pdf

Hallam, G. \& Creagh, T. (2010). Eportfolio use by university students in Australia: A review of the Australian Eportfolio Project. Higher Education Research and Development, 29(2), 179-193.

JISC (2008). Effective practice with eportfolios. Retrieved from: www.jisc.ac.uk/publications/publications/effectivepracticeportfolios.aspx.

Joyes,G., Grey,L., \& Hartnell-Young, E. (2010). Effective practice with eportfolios: How can the UK experience inform implementation? Australasian Journal of Educational Technology, 26(1), 15-27.

Kardos, R.L., Cook, J.M., Butson, R.J., \& Kardos, T.B. (2009). The development of an eportfolio for life-long reflective learning and auditable professional certification. European Journal of Dental Education. 13, 135-141.

Lin, Q. (2008). Preservice teachers' learning experiences of constructing e-portfolios online. Internet and Higher Education, 11(3-4), 194-200.

Lincoln, Y., \& Guba, E. (1985). Naturalistic Inquiry. Newbury Park: Sage Publications.

Lopez-Fernandez, O. \& Rodriguez-Illera, J. (2009). Investigating university students' adaptation to a digital learner course portfolio. Computers and Education, 52(3), 608616.

Lyons, N. (1998). Reflection in teaching: Can it be developmental? A portfolio perspective. Teacher Education Quarterly,25(1),115-127.

Lewis, L., \& Gerbic, P. (2012). The student voice in using eportfolios to address professional standards in a teacher education programme. Journal of Teaching and Learning for Graduate Employability, 3(1), 17 - 25. 
Mason, R., Pegler, C., \& Weller, M. (2004). Eportfolios: An assessment tool for online courses. British Journal of Educational Technology, 35(6), 717-727.

Milman, N. (2005). Web-based digital teaching portfolios: Fostering reflection and technology competence in preservice teacher education students. Journal of Technology and Teacher Education, 13(3), 373-396.

New Zealand Teachers Council. (2007). The Graduating Teacher Standards. Retrieved from: http://www.teacherscouncil.govt.nz/te/gts/

Pelliccione, L. \& Dixon, K. (2008). ePortfolios: Beyond assessment to empowerment in the learning landscape. In Hello! Where are you in the landscape of educational technology? Proceedings of $25^{\text {th }}$ Annual Ascilite Conference, Melbourne, Australia http://www.ascilite.org.au/conferences/melbourne08/procs/pelliccione.pdf

Ring, G. \& Foti, S. (2006). Using eportfolios to facilitate professional development among pre-service teachers (pp. 340-355) in A. Jafari \& C. Kaufman (Eds.), Handbook of research on eportfolios. Hershey, PA: Idea Group Reference.

Stephani, L., Mason,R., \& Pegler, C. (2007). The educational potential of e-portfolios. London, United Kingdom: Routledge.

Strudler, N. \& Wetzel, K. (2005). The diffusion of electronic portfolios in teacher education: Issues of initiation and implementation. International Journal of Technology and Design Education, 37(4), 422-433.

Wetzel, K., \& Strudler, N. (2006). Costs and benefits of electronic portfolios in teacher education: Student voices. Journal of Computing in Teacher Education, 22(3), 69-78.

Willis, H., Gravestock, P., \& Jenkins, M. (2006). Throwing a pebble into the pond: Eportfolios and student engagement. In Who's learning? Whose technology? Proceedings of $23^{\text {rd }}$ Annual Ascilite Conference, Sydney, Australia. http://www.ascilite.org.au/conferences/sydney06/proceeding/pdf papers/p68.pdf 